\title{
Alpha-2 Adrenergic Receptor Agonists Block Stress-Induced Reinstatement of Cocaine Seeking
}

Suzanne Erb, Ph.D., Paul K. Hitchcott, D. Phil., Heshmat Rajabi, B.Sc., Devin Mueller, M.A., Yavin Shaham, Ph.D., and Jane Stewart, Ph.D.

The alpha-2 adrenergic receptor agonists, clonidine, lofexidine and guanabenz, blocked stress- but not cocaineinduced reinstatement of cocaine seeking at doses that suppressed footshock-induced release of noradrenaline in prefrontal cortex and amygdala. Rats were trained to selfadminister cocaine (0.5 mg/kg/infusion, i.v; 10-12 days) and, after a drug-free period (7-13 days), were returned to the selfadministration chambers for daily extinction and reinstatement test sessions. Both intermittent footshock (15 min, $0.6 \mathrm{~mA})$ and cocaine priming $(20 \mathrm{mg} / \mathrm{kg}$, i.p.) reinstated extinguished drug seeking. Pretreatment with either clonidine $(20$, or $40 \mu \mathrm{g} / \mathrm{kg}$, i.p.) or lofexidine $(50,100,150$, or $200 \mu \mathrm{g} / \mathrm{kg}$, i.p.) attenuated footshock- but not cocaineinduced reinstatement of cocaine seeking. Guanabenz (640 $\mu \mathrm{g} / \mathrm{kg}$, i.p.), an alpha-2 agonist with low affinity for imidazoline type-1 receptors, also attenuated footshock- but not cocaine-induced reinstatement of cocaine seeking. The results point to an important role for NE systems in the effects of footshock on relapse to cocaine seeking.

[Neuropsychopharmacology 23:138-150, 2000] (C) 2000 American College of Neuropsychopharmacology. Published by Elsevier Science Inc. All rights reserved
KEY WORDS: Clonidine; Lofexidine; Cocaine Selfadministration; Relapse; Stress; Microdialysis

"Priming" injections of an abused drug can induce craving in abstaining addicts (e.g. Jaffe 1985) and reinstate drug-seeking in monkeys and rats with a history of drug self-administration (e.g., Stretch and Gerber 1973; de Wit and Stewart 1981). Another factor thought to be important to relapse in humans is stress (Kreek and Koob 1998). In a recent laboratory study, Sinha and colleagues (1999) found that induction of psychological

From the Center for Studies in Behavioral Neurobiology (SE, PKH, HR, DM, JS), Department of Psychology, Concordia University, Montreal, Quebec, Canada; Behavioral Neuroscience Department(YS), IRP/NIDA, Baltimore, MD.

Address correspondence to: Dr. Jane Stewart, Center for Studies in Behavioral Neurobiology, Department of Psychology, 1455 de Maisonneuve Blvd. W., Montreal, Quebec, Canada H3G 1M8 Tel: 514848-2193, Fax: 514-848-2817, E-mail: Stewart@CSBN.concordia.ca.

Received September 20, 1999; revised December 21, 1999; accepted December 28, 1999. stress provoked craving for drug in cocaine addicts. Using an animal model of stress-induced relapse, we and others have found in rats that exposure to brief intermittent footshock stress reliably reinstates heroin seeking (Shaham and Stewart 1995), cocaine seeking (Erb et al. 1996; Ahmed and Koob 1997; Mantsch and Goeders 1999), nicotine seeking (Buczek et al. 1999), and alcohol seeking (Lê et al. 1998).

In a search for neurotransmitter systems involved in stress-induced relapse, and for pharmacological manipulations that might prevent it, we explored in the present set of experiments the role of the noradrenergic (NE) system, comprised of a dorsal stream of neurons originating in the locus-coeruleus and a ventral stream of neurons originating in the lateral tegmental nuclei (Aston-Jones et al. 1995; Moore and Bloom 1979). Although the stress-related functions of the ventral projections have been only partially characterized (Cole and Robbins 1987; Hansen et al. 1980), NE projections from the LC have been directly implicated in a number 
of stress-related responses. For example, electrical stimulation of the LC has been found to induce anxiety and to result in activation of the autonomic nervous system, whereas local injections of the alpha-2 adrenergic receptor agonist clonidine, which acts to inhibit NE cell firing (Aghajanian and VanderMaelen 1982) and release (Carter 1997), has been found to decrease physiological and behavioral responses to stressors (Bremner et al. 1996; Redmond and Huang 1979).

We have recently reported that systemic or intracerebroventricular (i.c.v.) injections of clonidine block footshock-induced reinstatement of heroin seeking (Shaham et al. 2000), a finding that suggests an important role for brain NE in the mediation of stress-induced relapse. In previous studies, we have shown that another neurotransmitter system, corticotropin-releasing factor $(\mathrm{CRF})$, also plays an important role in mediating the footshock-induced reinstatement of both cocaine (Erb et al. 1998; Erb and Stewart 1999) and heroin seeking (Shaham et al. 1997) via its actions at extrahypothalamic brain sites. Interestingly, the CRF and NE systems interact in the brain in the modulation of stress responses (e.g., Li et al. 1998; Shimizu et al. 1994; Smagin et al. 1997; Valentino et al. 1991; Valentino and Wehby 1988), raising the possibility that an interaction between these systems underlies stress-induced relapse to drug seeking.

The present set of experiments had four main objectives. First, we assessed whether the effect of clonidine on stress-induced reinstatement previously observed in heroin-trained rats would generalize to rats with a history of cocaine self-administration. Second, we tested whether another alpha-2 adrenergic receptor agonist, lofexidine, would be equally effective. Third, because clonidine is known to bind at high affinity to the imidazoline type- $1\left(\mathrm{I}_{1}\right)$ receptor, we studied the effect of an alpha-2 adrenergic receptor agonist with low affinity for the $\mathrm{I}_{1}$ receptor, guanabenz (Piletz et al. 1994), on stress-induced reinstatement. Finally, we studied the effect of clonidine, lofexidine, and guanabenz on reinstatement of cocaine seeking induced by a priming injection of cocaine.

Before conducting the behavioral experiments, we assessed the ability of the three alpha- 2 adrenergic receptor agonists to suppress footshock-induced release of NE in two terminal regions, the prefrontal cortex (PFC) and amygdala (AMG). The PFC is a major terminal region of the dorsal NE system arising from the locus coeruleus, whereas the AMG receives input from both the dorsal and ventral systems.

\section{MATERIALS AND METHODS}

\section{Experiment 1: Effects of Clonidine, Lofexidine and Guanabenz on Footshock-Induced NE Release}

Subjects. The subjects were male Long-Evans rats (Charles River, Quebec) weighing 300-350 g at the be- ginning of the experiment. Throughout the experiment, animals were housed in a humidity- and temperaturecontrolled colony room on a reversed light-dark schedule (lights on 1730-0530 hours) and were given free access to standard laboratory rat chow and water. The experimental procedures followed the CCAC guidelines and were approved by the Animal Care Committee, Concordia University.

Surgery. Before surgery, rats were anesthetized with sodium pentobarbital $(65 \mathrm{mg} / \mathrm{kg}$, i.p.) and were injected with atropine sulfate $(0.6 \mathrm{mg} / \mathrm{ml} ; 0.2 \mathrm{ml} / \mathrm{rat}, \mathrm{SC})$ and antibiotic (Penlong, Rogar/STB Inc.; $0.1 \mathrm{ml} / \mathrm{rat}$, i.m.). Guide cannulae (20 gauge; Plastics One) were implanted for subsequent insertion of dialysis probes; one was placed in PFC and one in AMG in opposite hemispheres. The animals used to study the effects of guanabenz received a single guide cannula aimed at PFC. The hemisphere into which the respective guide cannulae were implanted was counterbalanced across treatments. The stereotaxic coordinates used (relative to bregma and skull surface) were as follows: AMG, AP $-3.0 \mathrm{~mm}, \mathrm{ML} \pm 4.5 \mathrm{~mm}, \mathrm{DV}-6.7 \mathrm{~mm}$; PFC, $\mathrm{AP}+3.2$ $\mathrm{mm}, \mathrm{ML} \pm 0.5 \mathrm{~mm}, \mathrm{DV}-1.5 \mathrm{~mm}$ (Paxinos and Watson 1997). Upon insertion, the shaft of the dialysis probe extended $1 \mathrm{~mm}$ from the guide cannulae. Implanted guide cannulae were secured to the skull with stainless steel screws and dental cement. Guide cannulae were closed with screw-in obdurators. All animals were returned to the colony room for a recovery period of no less than 1 week prior to testing.

Microdialysis. Microdialysis was conducted in four hexagonal testing chambers $(42 \times 39 \times 33.5 \mathrm{~cm})$ built from Plexiglas with wooden ceilings and stainless steel rod floors. Dark curtains were drawn around each chamber and lighting was provided on a reversed cycle by overhead light bulbs ( $15 \mathrm{~W})$. The dialysis probe consisted of a $1.8 \mathrm{~mm}$ (AMG) or $3.5 \mathrm{~mm}$ (PFC) length of semipermeable dialysis membrane (Spectra/Por; 240 $\mu \mathrm{m}$ o.d., 13000 M.W. cutoff), closed at one end and attached at the other to a $19 \mathrm{~mm}$ length of 26 gauge stainless-steel tubing. A 40- to 50-cm length of PE-20 tubing connected the other end of the stainless steel shaft to an infusion swivel stationed above the testing chamber that was in turn connected via PE-20 tubing to a variablespeed infusion pump. A small diameter, fused-silica tube extended internally through the probe, with one end resting $0.5 \mathrm{~mm}$ from the tip of the probe and the other end exiting the PE tubing $35 \mathrm{~cm}$ below the infusion swivel. The external length of PE-20 tubing was protected from damage by steel spring casings. The probes were designed so that the entire length of semi-permeable membrane extended below the guide cannula tip.

Separate squads of animals were used to examine the effects of each of the drugs tested. Within each squad, each animal was randomly assigned to the treatment 
condition. Animals that received vehicle injections were run in each squad, but were combined into a single group for statistical analysis. Final group sizes (PFC/ AMG) were as follows: vehicle $(\mathrm{n}=15 / 17)$, clonidine $20 \mu \mathrm{g} / \mathrm{kg}(\mathrm{n}=7 / 6)$, clonidine $40 \mu \mathrm{g} / \mathrm{kg}(\mathrm{n}=9 / 5)$, lofexidine $75 \mu \mathrm{g} / \mathrm{kg}(\mathrm{n}=6 / 6)$, lofexidine $150 \mu \mathrm{g} / \mathrm{kg}(\mathrm{n}=$ $5 / 6)$, guanabenz $640 \mu \mathrm{g} / \mathrm{kg}(\mathrm{n}=4, \mathrm{PFC})$. With the exception of the animals receiving guanabenz, all subjects were dialyzed twice, once in the PFC and once in the AMG with an interval of 3-4 weeks between tests.

The probes were inserted the day before the beginning of microdialysis testing. To prevent occlusion, artificial CSF (145 mM Na+, $2.7 \mathrm{mM} \mathrm{K}+, 1.22 \mathrm{mM} \mathrm{Ca} 2+$, $1.0 \mathrm{mM} \mathrm{Mg} 2+, 150 \mathrm{mM} \mathrm{Cl}-, 0.2 \mathrm{mM}$ ascorbate, $2 \mathrm{mM}$ $\mathrm{Na} 2 \mathrm{HPO} 4, \mathrm{pH} 7.4 \pm 0.1$ ) was perfused overnight at a rate of $0.06 \mu \mathrm{l} / \mathrm{min}$. Dialysate sampling and activity monitoring began the next morning. The dialysate flow rate was increased to $0.6 \mu \mathrm{l} / \mathrm{min}$, and baseline dialysate samples ( $\sim 12 \mu \mathrm{l} /$ sample) were collected every 20 min. Samples were collected until a stable baseline, defined as a minimum of three consecutive samples in which dialysate NE levels varied by $\pm 10 \%$, was achieved. Following the establishment of stable baseline $\mathrm{NE}$ levels, all animals received an i.p. injection $(1 \mathrm{ml} /$ $\mathrm{kg}$ ) of the appropriate drug or vehicle which was given $40 \mathrm{~min}$ before a $10 \mathrm{~min}$ period of footshock. Shocks were delivered on a variable time schedule at a mean interval of 40 seconds (10-70 seconds range); each shock (0.6 mA) was 0.5 seconds in duration. Samples were collected for a further 120 minutes (6 samples). Samples were immediately analyzed using one of two similar high-performance liquid chromatography systems with electrochemical detection (HPLC-EC). The samples $(10 \mu \mathrm{l})$ were loaded onto reverse-phase columns $(15 \times 0.46 \mathrm{~cm}$; HAISIL C18, $5 \mu \mathrm{m}$; Sci. Products \& Equipment, Concord, Ontario) through manual injection ports (Reodyne 7125; $20 \mu$ l loop); reduction and oxidation currents for $\mathrm{NE}$, dihydroxyphenylacetic acid (DOPAC), 5-hydoxyindoleacetic acid (5-HIAA) and homovanillic acid (HVA) were measured with dual-channel ESA coulometric detectors (Coulochem 5100, with a model 5021 conditioning cell and a model 5011 analytical cell, Sci. Products \& Equipment). The currents for NE were measured independent of those for DOPAC and HVA using separate channels of the Coulochem detectors. The mobile phases (sodium acetate $36 \mathrm{mM}$, SOS $3.1 \mathrm{mM}$, EDTA $100 \mu \mathrm{M}, 5 \%$ acetonitrile, adjusted to $\mathrm{pH} 3.7$ using glacial acetic acid) were circulated through each closed system at a flow rate of $1.4 \mathrm{ml} / \mathrm{min}$ by Waters 510 HPLC pumps. The peaks obtained for NE, DOPAC and HVA were integrated and quantified by EZChrom Chromatography Data System (Sci. Products \& Equipment). Dialysate samples from individual rats always were analyzed with the same HPLC-EC system, and the assignment of animals to each system was counterbalanced across all treatment groups. Food was removed from the chambers before sampling, but a water drinking tube was available. At the completion of testing, confirmation of correct probe placement was determined by examination of $30 \mu \mathrm{m}$ sections cut through the sites of probe placement stained with Cresyl violet.

\section{Experiment 2: Effects of Clonidine on Footshock- and Cocaine-Induced Reinstatement}

Subjects. The subjects were 25 male Long-Evans rats (Charles River, Quebec) weighing 350-425 g at the start of the experiment. The animals were maintained as described in Experiment 1.

Surgery. Animals were prepared for surgery as described in Experiment 1. An intravenous catheter (Dow Corning) was implanted in the right jugular vein. A $3-\mathrm{cm}$ length of silastic tubing was inserted into the vein (inner diameter $0.30 \mathrm{~mm}$, outer diameter $0.64 \mathrm{~mm}$ ) and was connected with heat shrink tubing to a 9-cm length of silastic tubing (inner diameter $0.51 \mathrm{~mm}$, outer diameter $0.94 \mathrm{~mm}$ ) that was passed subcutaneously to the top of the skull. The catheter was secured to the vein with silk sutures and exited into a connector (a modified 22 gauge cannula; Plastics One, Roanoke, VA) that was mounted to the skull with jeweler's screws and dental cement; a plastic cap was placed over the opening of the cannula. Animals were allowed 1-2 weeks to recover from surgery.

Apparatus. The self-administration chambers used in the experiments were equipped with a retractable lever (Med Associates, St Albans, VT) and a non-retractable "dummy" lever. Both levers were located $9 \mathrm{~cm}$ above the floor. An infusion pump (Razel Scientific Instruments, Stamford, CT) was activated by responses on the retractable, or "active," lever. Responses on the dummy lever were recorded but did not result in activation of the pump. Drug solution was delivered over a 10-s period in a volume of $65 \mu \mathrm{l}$. Throughout the infusion period, a white stimulus light just above the active lever was illuminated and additional responses during this time were recorded, but did not result in reactivation of the pump. Each self-administration chamber was fitted to deliver constant-current, intermittent, inescapable, electric footshock through a scrambler to the grid floor (Grason-Stadler Generator \#E1064GS or Med Associates). The footshock was delivered for 15 min according to a variable time schedule at a mean interval of $40 \mathrm{sec}-$ onds (10-70 seconds range). Each shock (0.6 mA) was 0.5 seconds in duration. This intensity of footshocks has been found using our apparatus to be the minimal required to induce reliable reinstatement.

Drugs. Cocaine $\mathrm{HCl}$ was obtained from $\mathrm{BDH}$ Chemicals (Toronto, Canada) and was dissolved in physiological saline. Clonidine $\mathrm{HCl}$ was purchased from Sigma 
(St Louis, MO) and was dissolved in physiological saline and injected i.p. $(0,20$, and $40 \mu \mathrm{g} / \mathrm{kg})$.

Procedure. Phase 1: Training. Rats were trained to selfadminister cocaine $\mathrm{HCl}(0.5 \mathrm{mg} / \mathrm{kg} /$ infusion, i.v. $)$ on a fixed-ratio-1 schedule of reinforcement during one daily 3-h self-administration session. Each day, half of the animals were brought to the operant chambers for their self-administration session in the morning, approximately three hours after lights off, and half of the animals were brought to the chambers in the afternoon, approximately seven hours after lights off. The group of animals assigned to the morning and afternoon sessions alternated daily so that by the end of training all animals had received an equal number of self-administration sessions at both times. It was important that all animals had similar experience self-administering early and late in the day since during Phase 2 all animals received extinction sessions in the morning followed by a test session that typically occurred in the afternoon. At the beginning of each session, a red house light was illuminated for 10 seconds before introduction of the retractable lever into the cage. The light just above the active lever was lit for the initial 30 seconds following presentation of the lever. The house light remained illuminated throughout the session. As indicated previously, responses on the active lever resulted in activation of the infusion pump and illumination of the light above the lever for the 10 seconds of drug delivery. Additional lever presses during the drug-delivery period were recorded but did not result in reactivation of the pump. Training conditions were in place for 10 to 12 days. At the end of training, animals were left undisturbed in the colony room for 7 to 13 days. Subsequently, extinction and testing took place. In this experiment and in Experiment 3B, groups of animals were assigned to different doses of the test drugs. All animals in each group were then subjected to three test conditions; saline, cocaine and footshock.

Phase 2: Extinction and testing. During extinction and testing, which occurred over four consecutive days, animals were housed 24 hours per day in the self-administration chambers. Food and water were freely available to animals, except during daily extinction and test sessions. Animals were brought to the chambers in the evening preceding the first day of extinction and testing. Since two separate groups of rats were run each day during the training phase, one group of animals was tested in the first four days of Phase 2 and the other group of animals was tested in the next four days. During extinction and testing, all of the conditions that were present during training were maintained except that lever presses did not result in cocaine infusions.

In this and all subsequent reinstatement experiments, animals were given several daily 1 -h extinction sessions separated by intervening periods in which the lever was withdrawn. On day 1 , animals were given four extinction sessions; on days $2-4$, animals were given two to three extinction sessions, sufficient to establish a baseline level of responding of 15 or fewer responses in one hour, followed by a $180 \mathrm{~min}$ test session. The duration of the intervening periods was kept constant for each experiment and corresponded to the delay required for drug absorption between pretreatment injections and the start of the test. In the present experiment, the duration of intervening periods was $40 \mathrm{~min}$.

At test, separate groups of animals were pretreated with either 0,20 , or $40 \mu \mathrm{g} / \mathrm{kg}$, i.p., clonidine before each of three tests for reinstatement (saline, cocaine, and footshock), given on consecutive days and in a counterbalanced order. Clonidine was injected $40 \mathrm{~min}$ before the lever was inserted. For the saline and cocaine priming tests, animals were given a non-contingent, i.p., injection of saline or cocaine $(20 \mathrm{mg} / \mathrm{kg}) 5 \mathrm{~min}$ before lever insertion. For the footshock tests, animals were exposed to the 15-min brief intermittent footshock stress immediately before insertion of the lever. Test sessions were 3-h in duration. The dose of cocaine and footshock parameters were chosen on the basis of previous work from this laboratory (Erb et al. 1996; Erb et al. 1998; Shaham et al. 1998). The doses of clonidine were chosen on the basis of reinstatement experiments we have conducted with heroin-trained rats (Shaham et al. 2000).

\section{Experiment 3A: Effects of Lofexidine on High Rates of Responding for Sucrose}

Because the pharmacological profile for lofexidine has not been as well characterized as that for clonidine, an experiment was conducted to establish whether, and at what doses, lofexidine induces performance deficits. The doses in the tests for reinstatement were chosen on the basis of results obtained in this experiment.

Subjects. The subjects were 8 male Long-Evans rats (Charles River, Quebec) weighing 400-550 g at the beginning of the experiment. Rats were previously used in an experiment aimed at studying footshock-induced reinstatement of sucrose seeking (Buczek et al. 1999). Animals were maintained under similar conditions to those described in Experiment 1.

Apparatus. Each self-administration chamber was equipped with two stationary levers, symmetrically centered on one side panel, $5 \mathrm{~cm}$ above the floor. Responses on one lever, the "active" lever, activated a pump (Razel Sci. Stamford, CT). Responses on the other lever, the "dummy" lever, were recorded but were without consequence. Activation of the pump resulted in a 20 -second delivery of $0.18 \mathrm{ml}$ sucrose solution to a liquid drop receptacle located between the two levers. Throughout the sucrose delivery period, a white stimulus light just above the active lever was illuminated and 
additional responses during this time were recorded but did not result in reactivation of the pump.

Drugs. Lofexidine $\mathrm{HCl}$ was generously supplied by Keith Davies, Britannia Pharmaceuticals Ltd., UK. The drug was dissolved in physiological saline and injected i.p. $(0,80,120,160$ or $200 \mu \mathrm{g} / \mathrm{kg})$.

Procedure. Animals that had previously learned to self-administer sucrose in a different study (Buczek et al. 1999) were subsequently given five sessions over five consecutive days in which they self-administered a $30 \%$ sucrose solution on an FR-1 schedule. In subsequent daily sessions, animals were injected with either vehicle $(0 \mu \mathrm{g} / \mathrm{kg})$ or lofexidine $(80,120,160$ or $200 \mu \mathrm{g} /$ $\mathrm{kg}$, i.p.) $60 \mathrm{~min}$ before the start of the self-administration session. All animals received all doses of lofexidine in a counterbalanced order; the highest dose of lofexidine was tested twice. Each session in which animals were treated with lofexidine was followed by a saline pretreatment session to minimize the possibility of carry-over effects of the drug.

\section{Experiment 3B: Effects of Lofexidine on Footshock- and Cocaine-Induced Reinstatement}

Subjects. The subjects were 49 male Long-Evans rats (34 from Charles River, Quebec; 15 from Harlan Sprague Dawley, USA) weighing 350-400 $\mathrm{g}$ at the beginning of the experiment. The animals were maintained as described in Experiment 1. There were no obvious differences in responding between animals from the two suppliers in any phase of the experiment.

Procedure. Phase 1: Training. Animals were trained to self-administer cocaine under the conditions described in Experiment 2.

Phase 2: Extinction and testing. In this experiment the intervening periods, as described above, were $60 \mathrm{~min}$ in duration. At test, separate groups of animals were pretreated with either $0,50,100,150$, or $200 \mu \mathrm{g} / \mathrm{kg}$, i.p., lofexidine before each of three tests for reinstatement (saline, cocaine, and footshock stress), given on consecutive days and in a counterbalanced order (see Experiment 2). Lofexidine was injected $60 \mathrm{~min}$ before the insertion of the lever. Test sessions were 3-h in duration. The doses of lofexidine were chosen on the basis of the results obtained in Experiment 3A.

\section{Experiment 4: Effects of Guanabenz on Footshock- and Cocaine-Induced Reinstatement}

Subjects. The subjects were 18 male Long-Evans rats (Charles River, Quebec) weighing 350-400 g at the beginning of the experiment. The animals were maintained as described in Experiment 1.

Drug. Guanabenz was purchased from Sigma (St Louis, MO) and was dissolved in physiological saline and injected i.p. (0, and $640 \mu \mathrm{g} / \mathrm{kg})$.
Procedure. Phase 1: Training. Animals were trained to self-administer cocaine under the conditions described in Experiment 2.

Phase 2: Extinction and testing. In this experiment the intervening periods, as described above, were $60 \mathrm{~min}$ in duration. At test, animals were pretreated with 0 or 640 $\mu \mathrm{g} / \mathrm{kg}$ guanabenz, i.p., before each of two tests for reinstatement (no footshock, footshock or saline, cocaine), given on consecutive days (see Experiment 2). Guanabenz was injected $60 \mathrm{~min}$ before the insertion of the lever. Test sessions were 3 -h in duration. The dose of guanabenz was chosen on the basis of its substitutability for $40 \mu \mathrm{g} / \mathrm{kg}$ clonidine in a drug discrimination procedure (Bennett and Lal 1982).

\section{Statistical Analyses}

Microdialysis data were analyzed using a mixed-factor ANOVA for concentration of extracellular NE in $20 \mathrm{~min}$ dialysate samples; the between-subjects factor was dose of clonidine $(0,20,40 \mu \mathrm{g} / \mathrm{kg})$, lofexidine $(0,75$, or 150 $\mu \mathrm{g} / \mathrm{kg}$ ), or guanabenz (0 or $640 \mu \mathrm{g} / \mathrm{kg}$ ) and the repeated measure was time. Significant time by dose interactions were subjected to one-way ANOVAs for the factor of dose at specific time points. When appropriate, post hoc tests (Fisher's LSD, $p<.05$ ) were conducted to compare vehicle $(0 \mu \mathrm{g} / \mathrm{kg})$ to drug conditions.

The two dependent measures in the tests for reinstatement were number of responses on the active lever (infusions + time out responses) and number of responses on the inactive lever in three hours. All behavioral data are presented as means \pm SEM. Because of considerable variability in the number of responses made in the different tests for reinstatement, the nonparametric statistics for related (Friedman and Wilcoxon) and unrelated (Kruskal-Wallis and MannWhiney) samples were used where appropriate.

For the sucrose study (Experiment 3A) the dependent measures were the number of responses on the active (reinforced + timeout responses) and inactive levers and the number of reinforcements obtained. Repeated measures ANOVAs were conducted with dose as the within-subject factor. When appropriate, post hoc tests (Fisher's LSD, $p<.05$ ) were conducted to compare vehicle $(0 \mu \mathrm{g} / \mathrm{kg})$ to drug conditions.

\section{RESULTS}

\section{Experiment 1: Effects of Clonidine, Lofexidine and Guanabenz on Footshock-Induced NE Release}

Figure 1 shows basal and footshock-induced levels of NE in PFC (top row) and/or AMG (bottom row) after injection at Time 0 with clonidine (left panel), lofexidine (center panel), or guanabenz (right panel). Mixed-factor ANOVAs revealed significant Time by Dose interac- 


\section{NE in PREFRONTAL COR'TEX}

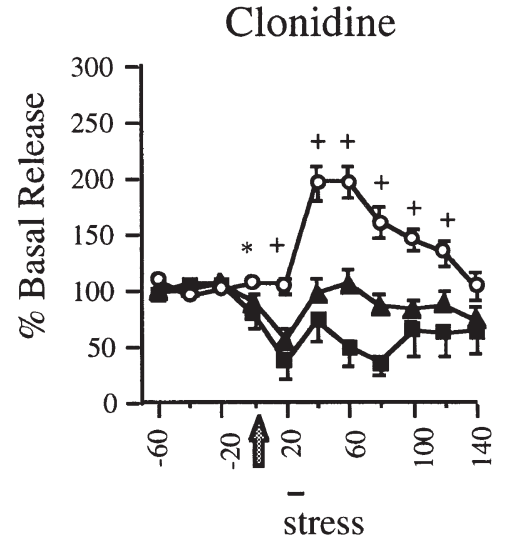

NE in AMYGDALA

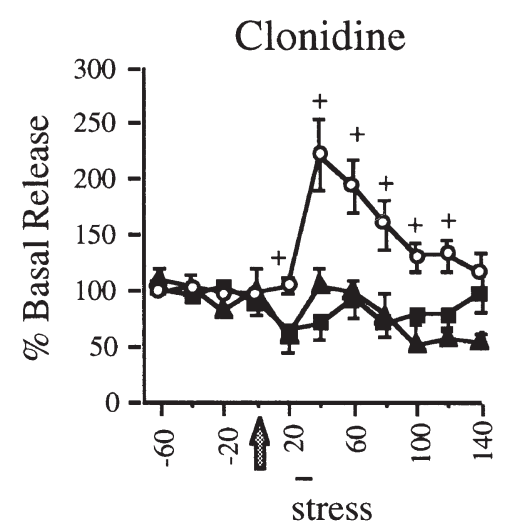

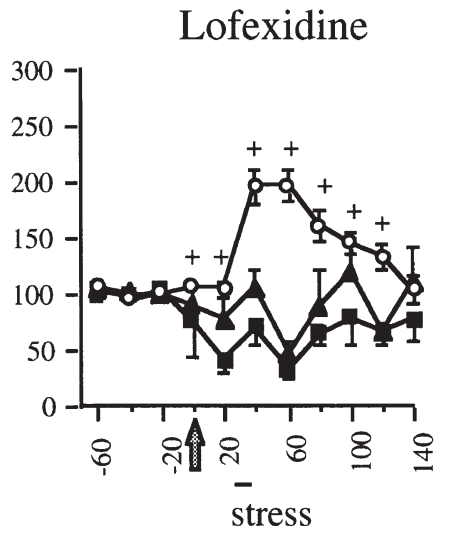
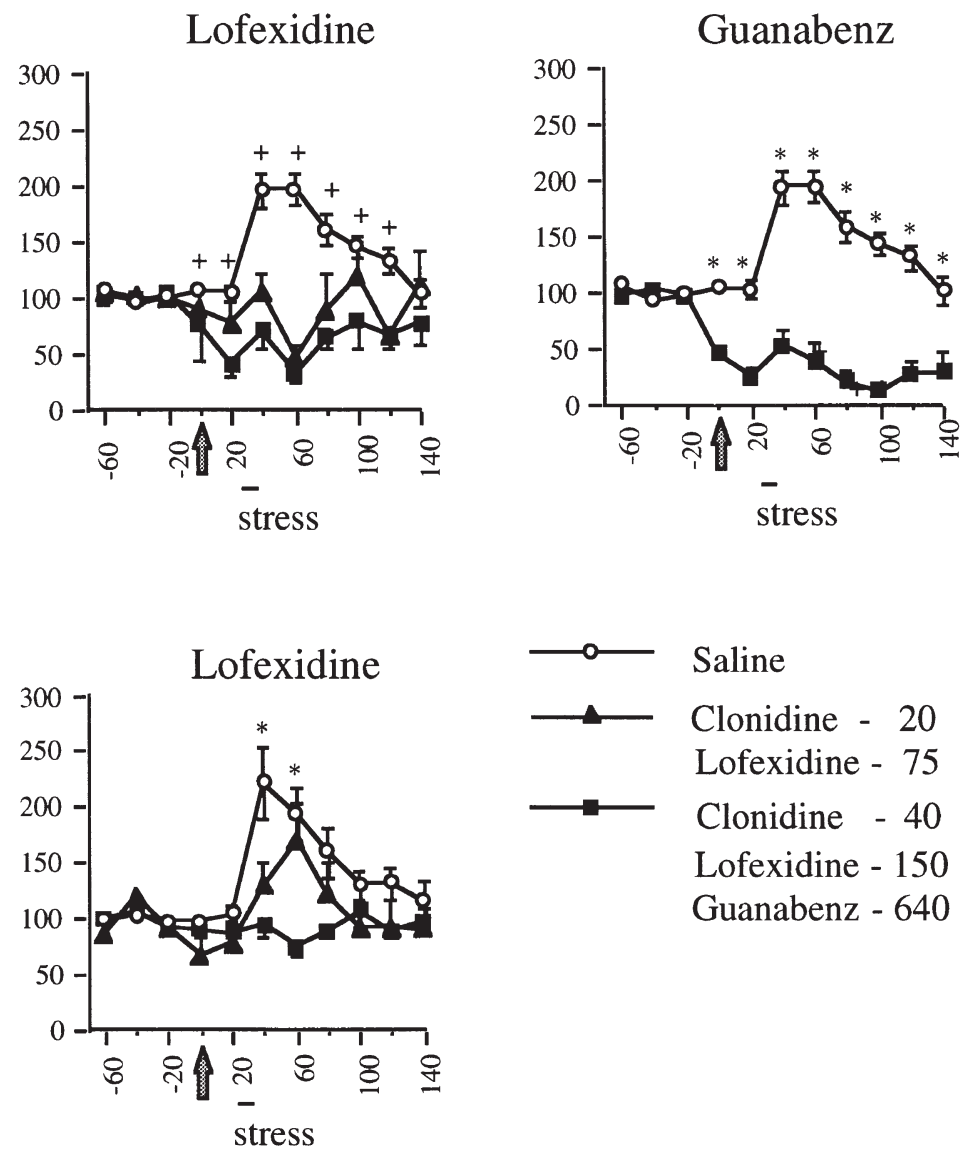

Saline

Clonidine - 20

Lofexidine - 75

Clonidine - 40

Lofexidine - 150

Guanabenz - 640

Figure 1. Microdialysis - Prefrontal cortex and amygdala: Mean ( \pm SEM) NE concentrations in 20 min dialysate samples in prefrontal cortex and amygdala. Animals were injected with either clonidine $(0,20$, or $40 \mu \mathrm{g} / \mathrm{kg}$, i.p.), lofexidine $(0,75$, or $150 \mu \mathrm{g} / \mathrm{kg}$, i.p.), or guanabenz (0 or $640 \mu \mathrm{g} / \mathrm{kg}$, i.p.) at Time 0, and $40 \mathrm{~min}$ later were exposed to 10 min of intermittent footshock stress $(0.6 \mathrm{~mA})$. Significant Time by Dose interactions were obtained for the prefrontal cortex and amygdala after clonidine $(\mathrm{F}(16,192)=4.40, p<.01$ and $\mathrm{F}(16,168)=2.03, p<.03$, respectively), lofexidine $(\mathrm{F}(16,168)=5.09 p<.01$ and $\mathrm{F}(16,192)=2.09, p<.03$, respectively), and guanabenz $(\mathrm{F}(8,120)=6.22, p<.001)$. ${ }^{*}$ Different from high dose only, $p<.05 . ;+$ different from both other doses, $p<.05$.

tions in both brain regions and for each of the three drugs. The statistics for each of these interactions are indicated in the figure legend. One-way ANOVAs conducted at specific time points were, when statistically significant, followed by post-hoc comparisons (Fisher's LSD). Significant differences are indicated in Figure 1. See Figure 2 for a diagram showing the areas of the PFC and AMG where the active regions of the dialysis probes were located.

\section{Experiment 2: Effects of Clonidine on Footshock- and Cocaine-Induced Reinstatement}

Training and Extinction. The mean $( \pm$ SEM) number of infusions of $0.5 \mathrm{mg} / \mathrm{kg}$ cocaine made in the 3-h session on the last two days of training was $32.24( \pm 2.77)$ and $25.76( \pm 2.96)$, respectively. The mean $( \pm$ SEM $)$ number of responses (infusions + time out responses) made during the first three 1-h extinction sessions on day 1 of Phase 2, was $28.92( \pm 2.81), 13.16( \pm 2.03)$, and $9.68( \pm 2.04)$. There was no difference in the rate of extinction between animals tested in the first four days of Phase 2 and those tested four days later.

Tests for reinstatement. The number of responses made on the active and inactive levers during each 3-h test for reinstatement following pretreatment with clonidine is shown in Figure 3A. Figure 3B shows the number of responses on the active lever during each hour of testing. It can be seen that pretreatment with 20 or $40 \mu \mathrm{g} / \mathrm{kg}$ clonidine blocked footshock-induced re- 

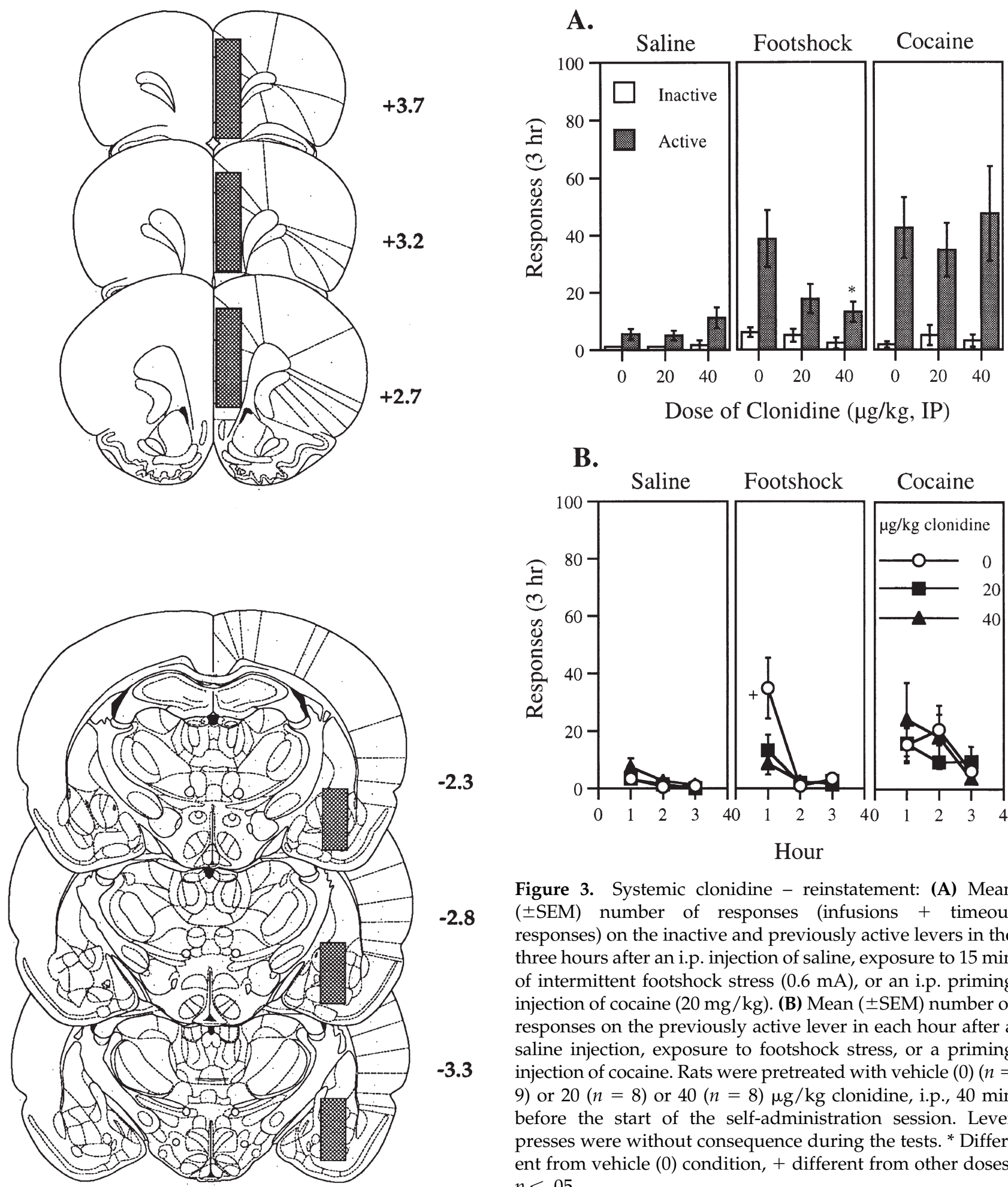

$-2.3$

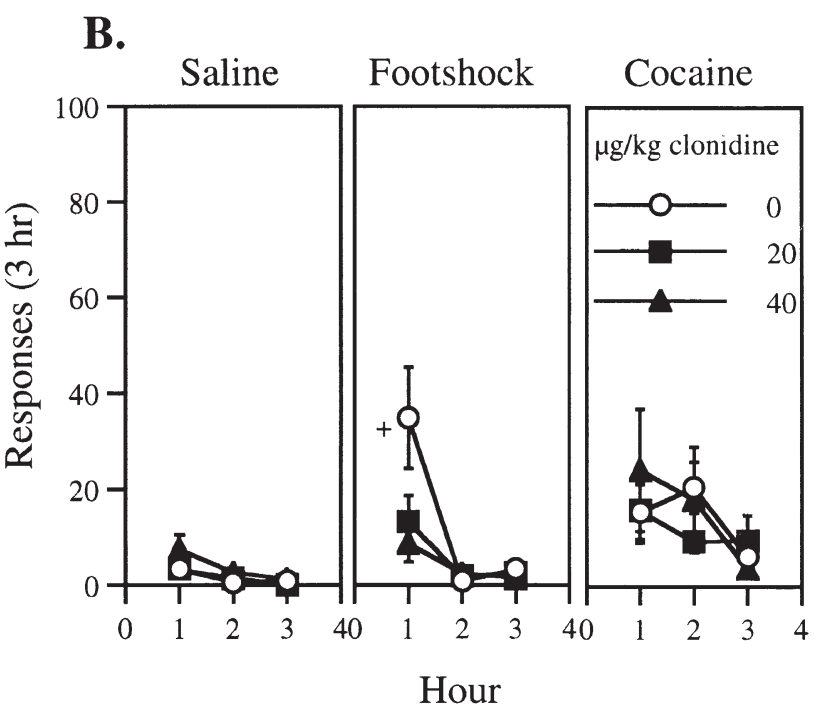

Figure 3. Systemic clonidine - reinstatement: (A) Mean $( \pm \mathrm{SEM})$ number of responses (infusions + timeout responses) on the inactive and previously active levers in the three hours after an i.p. injection of saline, exposure to $15 \mathrm{~min}$ of intermittent footshock stress $(0.6 \mathrm{~mA})$, or an i.p. priming injection of cocaine $(20 \mathrm{mg} / \mathrm{kg})$. (B) Mean $( \pm S E M)$ number of responses on the previously active lever in each hour after a saline injection, exposure to footshock stress, or a priming injection of cocaine. Rats were pretreated with vehicle $(0)(n=$ 9) or $20(n=8)$ or $40(n=8) \mu \mathrm{g} / \mathrm{kg}$ clonidine, i.p., $40 \mathrm{~min}$ before the start of the self-administration session. Lever presses were without consequence during the tests. * Different from vehicle (0) condition, + different from other doses, $p<.05$.

Figure 2. Diagrams showing the regions (shaded areas) of the prefrontal cortex (top panel; 46 placements) and amygdala (bottom panel; 40 placements) in which the active region of the dialysis probes were found to be placed after histological analysis. The values of the right of each figure indicated mm from bregma (Paxinos and Watson 1997).

lapse to cocaine seeking, but had no effect on relapse induced by a priming injection of cocaine. Kruskal-Wallis tests conducted at each hour of testing revealed a significant effect of dose of clonidine in the footshock condition in Hour 1, when most of the responding occurred 
$\left(X^{2}(2)=6.0, p<.05\right.$, footshock $)$; both doses of clonidine were effective $(p<.05)$. There were no significant effects of clonidine in either the saline or cocaine conditions in Hour 1; no effects were seen in any of the test conditions in Hours 2 or 3. Figure 3A shows that responding on the inactive lever was low under all pretreatment and test conditions. This was the case in all subsequent reinstatement experiments, where there were no significant effects of the number of responses on the inactive lever.

\section{Experiment 3A: Effects of Lofexidine on Responding for Sucrose}

Figure 4 shows the total number of responses (reinforced + time out responses) on the active and inactive levers, and the number of sucrose reinforcements made, following injections of vehicle $(0 \mu \mathrm{g} / \mathrm{kg})$ or lofexidine. There was no effect of lofexidine on the number of responses on the active lever, $\mathrm{F}(4,28)=1.79$, ns. There were, however, dose effects on the number of reinforcements and number of responses on the inactive lever $(\mathrm{F}(4,28)=2.80, p<.05$ and $\mathrm{F}(4,28)=2.85, p<.05$, respectively); this reflects the fact that when compared with the vehicle $(0 \mathrm{~g} / \mathrm{kg})$ condition, animals obtained fewer sucrose reinforcements and made fewer responses on the inactive lever following pretreatment with the highest dose of lofexidine $(200 \mu \mathrm{g} / \mathrm{kg})$.

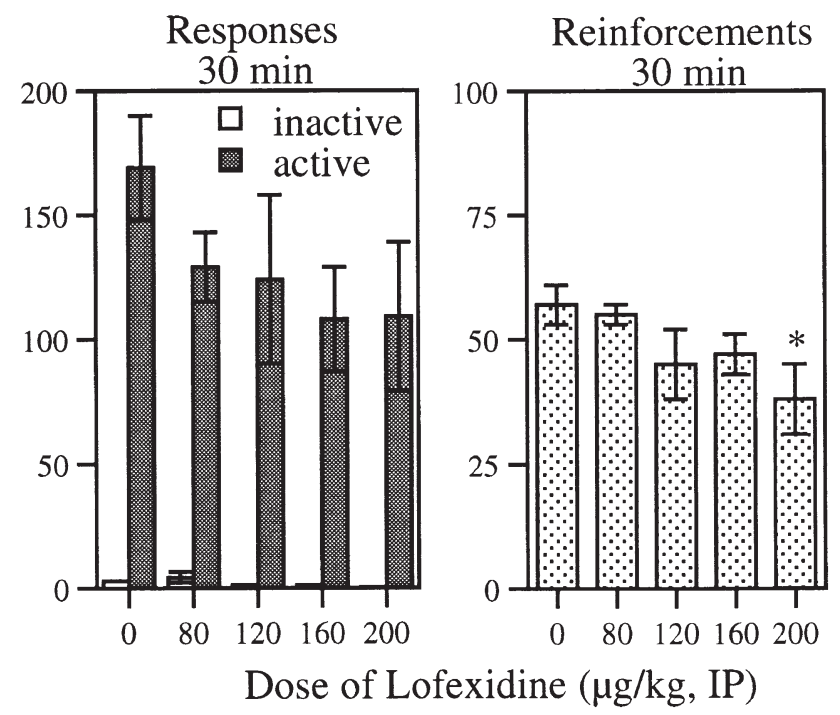

Figure 4. Systemic lofexidine - responding for sucrose: Mean $( \pm S E M)$ number of responses on the inactive and active levers $60 \mathrm{~min}$ after pretreatment with $0,80,120,160$ and $200 \mu \mathrm{g} / \mathrm{kg}$ lofexidine, i.p. $(n=8)$. Responding on the active lever was reinforced with $0.18 \mathrm{ml}$ of a $30 \%$ sucrose solution. * Different from vehicle (0) condition, $p<.05$.

\section{Experiment 3B: Effects of Lofexidine on Footshock- and Cocaine-Induced Reinstatement}

Training and Extinction. The mean $( \pm$ SEM) number of cocaine infusions made in the 3-h session on the last two days of training was $30.07( \pm 2.37)$ and 30.91 $( \pm 2.06)$, respectively. On day 1 of extinction, the mean $( \pm$ SEM) number of responses made in the first three 1-h extinction sessions (infusions + time out responses) was $31.32( \pm 3.22), 16.84( \pm 3.29)$, and $16.23( \pm 2.35)$. There was no difference in the rate of extinction between animals tested in the first four days and those tested in the subsequent four days of Phase 2.

Tests for Reinstatement. Figure 5A shows the number of responses made on the active and inactive levers during each 3-h test for reinstatement following pretreatment with vehicle $(0 \mu \mathrm{g} / \mathrm{kg})$ or lofexidine. Figure $5 \mathrm{~B}$ shows the number of responses on the active lever during each hour of testing. It can be seen that both footshock stress and priming injections of cocaine induced reinstatement of cocaine seeking behavior. Only the effect of footshock stress was attenuated by lofexidine. This is confirmed by the Kruskal-Wallis tests conducted for the 3-h tests for reinstatement where the only significant effect was found in the footshock condition $\left(\mathrm{X}^{2}(4)=10.50, p<.05\right)$. Subsequent Mann-Whitney comparisons revealed a significant difference between the 0 and $150 \mu \mathrm{g} / \mathrm{kg}$ and 0 and $200 \mu \mathrm{g} / \mathrm{kg}$ lofexidine doses ( $p \mathrm{~s}<.05)$; furthermore, the response to footshock after 150 and $200 \mu \mathrm{g} / \mathrm{kg}$ doses did not differ from the responses in the saline condition. Separate analyses conducted at each hour of testing revealed a significant effect, again, only in Hour 1 of testing $\left(X^{2}(4)=17.31, p<\right.$ .01 , footshock), when all doses of lofexidine blocked the footshock effect $(p \mathrm{~s}<.05)$.

\section{Experiment 4: Effects of Guanabenz on Footshock- and Cocaine-Induced Reinstatement}

Training. The mean $( \pm$ SEM) number of infusions of cocaine made in the 3-h session on the last two days of training was $36.63( \pm 3.56)$ and $40.12( \pm 3.65)$, respectively.

Tests for Reinstatement. Figure 6 shows the number of responses made on the active lever in tests for reinstatement after pretreatment with either 0 or $640 \mu \mathrm{g} / \mathrm{kg}$ guanabenz. It can be seen that guanabenz attenuated the effect of footshock stress. A Friedman analysis on the footshock and no footshock tests revealed a significant effect of test condition $\left(\mathrm{X}^{2}(3)=8.36, p<.05\right)$ and subsequent comparisons using the Wilcoxon test showed that the footshock $(0 \mu \mathrm{g} / \mathrm{kg})$ condition differed from the others $(p s<.05)$. Inspection of Figure 6 also reveals what appears to be a reduction in responding in the cocaine test following pretreatment with guanabenz. However, a comparison of the scores on the cocaine test using the Mann-Whitney revealed no signifi- 
A.

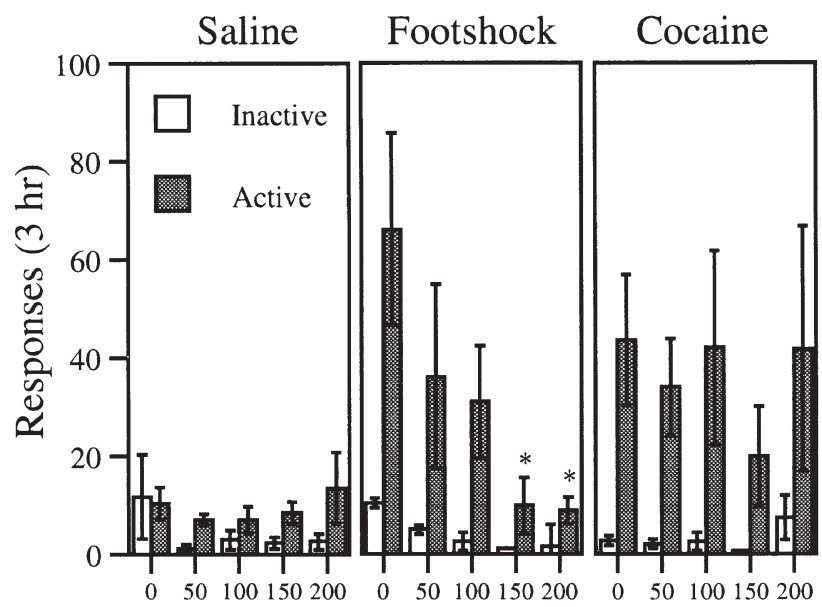

Dose of Lofexidine $(\mu \mathrm{g} / \mathrm{kg}, \mathrm{IP})$

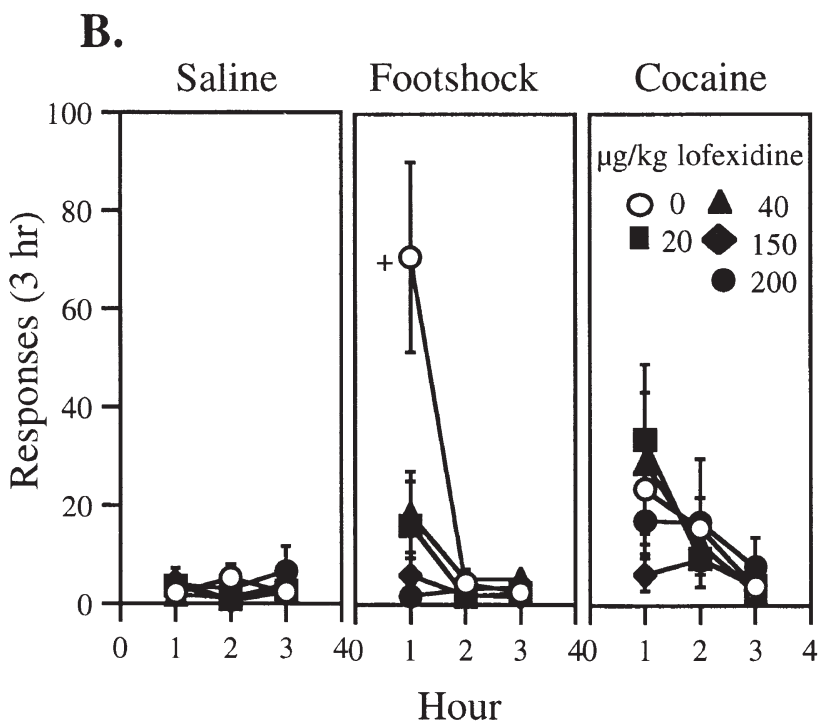

Figure 5. Systemic lofexidine - reinstatement: (A) Mean $( \pm \mathrm{SEM})$ number of responses (infusions + timeout responses) on the inactive and previously active levers in the three hours after an i.p. injection of saline, exposure to 15 min of intermittent footshock stress $(0.6 \mathrm{~mA})$, or an i.p. priming injection of cocaine $(20 \mathrm{mg} / \mathrm{kg})$. (B) Mean ( \pm SEM) number of responses (infusions + timeout responses) on the previously active lever in each hour after saline injection, exposure to footshock stress, or a priming injection of cocaine. Rats were pretreated with vehicle $(0)(n=9)$ or $50(n$ $=11), 100(n=11), 150(n=9)$, or $200(n=9) \mu \mathrm{g} / \mathrm{kg}$ lofexidine, i.p., $60 \mathrm{~min}$ before the start of the self-administration session. Lever presses were without consequence during the tests. ${ }^{*}$ Different from vehicle (0) condition, + different from other doses, $p<.05$.

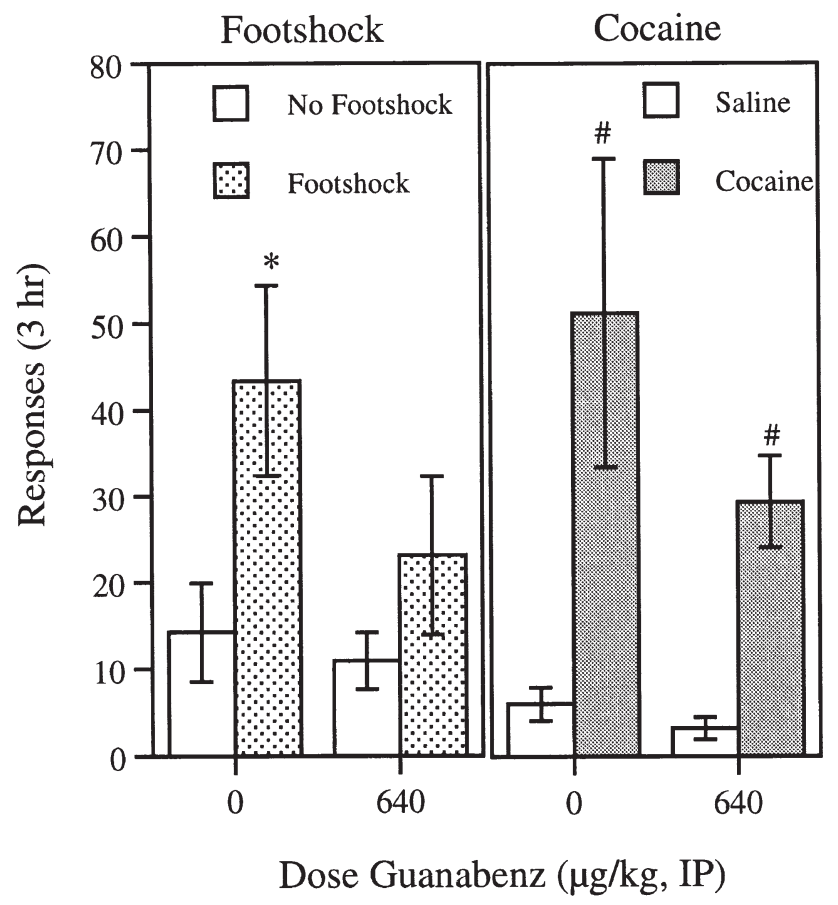

Figure 6. Systemic guanabenz - reinstatement: Mean $( \pm$ SEM) number of responses (infusions + time out responses) on the previously active lever during 3-hour test sessions (no footshock and footshock; saline and cocaine) after pretreatment with 0 or $640 \mu \mathrm{g} / \mathrm{kg}$ guanabenz. * Different from all other conditions, $p<.05$. \# different from saline test condition, $p<.05$.

cant difference between the two groups ( 0 and $640 \mu \mathrm{g} /$ $\mathrm{kg} ; \mathrm{z}=0.73, p=.46$ ).

\section{DISCUSSION}

Two major findings emerge from the present series of experiments. First, systemic injections of clonidine and lofexidine attenuate the footshock-induced reinstatement of cocaine seeking, but have no effect on reinstatement induced by priming injections of cocaine. Second, the alpha-2 adrenergic receptor agonist, guanabenz, which unlike clonidine and lofexidine has a low affinity for $I_{1}$ receptors (Piletz et al. 1994), also attenuates footshock-induced reinstatement. These effects were obtained by drugs that at similar doses and under similar stress parameters to those used in the tests for reinstatement suppressed the footshock-induced increase in NE release in AMG and/or PFC in naïve animals. These findings suggest that reduction of brain NE activity may be an effective way to prevent stress-induced relapse to cocaine seeking.

The finding that clonidine, lofexidine, and guanabenz attenuate footshock-induced but not cocaine- 
induced reinstatement was not unexpected in view of our previous findings that stress- and drug-induced relapse can be dissociated pharmacologically. As mentioned, CRF receptor antagonists attenuate footshockinduced, but not drug-induced relapse (Erb et al. 1998; Shaham et al. 1997). From these data it seems logical to consider that footshock stress may have its effects on reinstatement through an interaction between the CRF and NE systems. Although the present data do not bear directly on where in the brain this interaction might take place, we have recent data that do (Erb and Stewart 1999; Shaham et al. 2000). We found first that 6-OHDA lesions of the ventral NE pathway attenuate footshock-induced reinstatement of heroin seeking, whereas injections of clonidine or ST-91 (a less diffusible charged analogue of clonidine) directly into the locus coeruleus were not effective (Shaham et al. 2000). On the basis of this work and additional studies on the site of action of CRF and its receptor antagonist, D-Phe $\mathrm{CRF}_{12-41}$, we have proposed that the effects of footshock on relapse may be mediated by the interaction between $\mathrm{NE}$ and CRF in the bed nucleus of the stria terminalis (BNST) and/or the central nucleus of the AMG. We have found that local injections of CRF and its receptor antagonist, D-Phe-CRF ${ }_{12-41}$, in the BNST act to induce and block stress-induced reinstatement, respectively (Erb and Stewart 1999). The ventral NE bundle provides the primary source of NE to both the BNST and central nucleus of the AMG (Aston-Jones et al. 1995; Terenzi and Ingram 1995) and both structures are known to contain CRF cell bodies (Phelix and Paull 1990; Veinante et al. 1997); furthermore, the CRF cell bodies of the central nucleus of the AMG project to the BNST (Sakanaka et al. 1986).

Whereas footshock-induced reinstatement may be mediated by the NE and CRF systems, the effects of priming injections of psychostimulant and opioid drugs on relapse to drug seeking have been shown to be mediated by the midbrain dopaminergic system (Self and Nestler 1998; Stewart 1984; Stewart and Vezina 1988). It is interesting, however, that clonidine is known to have effects on the functioning of midbrain dopaminergic neurons (Lategan et al. 1990). For example, it has been shown that systemic injections of alpha-2 adrenergic receptor agonists decrease dopamine release in the nucleus accumbens (Murai et al. 1998) and the PFC (Gobert et al. 1998). These effects may be due to the effect of alpha-2 adrenergic receptor agonists on dopamine cell firing. Grenhoff and Svensson (1989) have shown that clonidine regularizes midbrain dopamine cell firing in anesthetized rats, an effect that should reduce dopamine release from terminals (Roth et al. 1987). These changes, however, may not have been sufficient to prevent increases in extracellular dopamine in the nucleus accumbens, in the face of cocaine-induced blockade of dopamine reuptake. It is also possible that previous exposure to cocaine during the self-adminis- tration phase of the study served to increase dopamine availability in the nucleus accumbens, thereby increasing sensitivity to a priming injection of the drug (Kalivas and Duffy 1993).

The effects of clonidine and lofexidine observed in this study could have been mediated through their actions at $\mathrm{I}_{1}$ rather than alpha-2 receptors. The $\mathrm{nM}$ affinity of clonidine for the alpha-2 receptor is $28 \pm 2.6$ and for the $\mathrm{I}_{1}$ receptor is $0.99 \pm 0.43$ (Ernsberger et al. 1990); the affinity of lofexidine for these receptors is almost identical (Buccafusco et al. 1995). Alpha-2 and $I_{1}$ receptors have been shown, however, to be differentially involved in biochemical and behavioral effects of alpha-2 adrenergic receptor agonists (for a review see Piletz et al. 1994). For example, in drug discrimination studies, alpha-2 receptors appear to be responsible for a clonidine-induced cue, for which both lofexidine and guanabenz (a compound with $\mathrm{nM}$ affinity for alpha-2 receptor of $7.2 \pm 0.6$ and for the $\mathrm{I}_{1}$ receptor of $>1,000,000$ ) substitute dose-dependently (Bennett and Lal 1982; Jordan et al. 1993; Lal and Yaden 1985). On the other hand, $\mathrm{I}_{1}$ receptors of the medulla are thought to mediate the antihypertensive actions of these drugs (Buccafusco et al. 1995; but see Guyenet 1997). Although not definitive in view of the fact that guanabenz was not tested independently for rate-reducing effects, it appears unlikely that the attenuation of the footshock-induced reinstatement of cocaine seeking was $\mathrm{I}_{1}$-receptor mediated; guanabenz, a drug with a low affinity for the $I_{1}$ receptor, attenuated footshock-induced reinstatement of cocaineseeking at a dose that has been shown to substitute for $40 \mu \mathrm{g} / \mathrm{kg}$ clonidine in a drug discrimination task (Bennett and Lal 1982).

Three issues might be seen to complicate the interpretation of the present findings. First, clonidine, lofexidine and guanabenz might affect motor performance (see Monti 1982; Stanford 1995); second, these drugs might act at peripheral rather than central receptors (Buccafusco et al. 1995); and finally, it is possible that the analgesic actions of these drugs (see Codd et al. 1995) mediate their effect on footshock-induced reinstatement. With respect to the first, it is unlikely that the effects were due to a performance deficit. In the saline and cocaine priming conditions, neither clonidine, lofexidine nor guanabenz reduced responding on the active lever. Furthermore, the doses of clonidine and lofexidine used in the tests for reinstatement were chosen because they had little or no effect on high rates of responding for sucrose. After the highest dose of clonidine tested $(40 \mu \mathrm{g} / \mathrm{kg})$ in sucrose-trained animals (Shaham et al. 2000), animals responded nearly 100 times in 20 min; likewise, in Experiment 3A, animals injected with the highest dose of lofexidine $(200 \mu \mathrm{g} / \mathrm{kg}) \mathrm{ob}-$ tained close to 40 reinforcements in $30 \mathrm{~min}$ and demonstrated no significant reduction in response rate.

The possibility that the effects observed in the 
present study were due to the actions of the alpha-2 agonists at peripheral rather than central receptors also seems unlikely. First, we found in a study with herointrained rats that i.c.v. injections of clonidine were as effective as systemic injections in blocking the footshockinduced reinstatement (Shaham et al. 2000). Additionally, we have given systemic injections of $40 \mu \mathrm{g} / \mathrm{kg}$ ST-91 (the charged analogue of clonidine which does not effectively cross the blood brain barrier) to cocainetrained animals and have found that ST-91-treated animals show a comparable footshock-induced reinstatement of responding $(90.75 \pm 26.37$ in three hours $)$ to vehicle-treated animals $(115.63 \pm 24.49$ in three hours; unpublished data). It would appear, therefore, that the effects of systemic injections of clonidine on footshock-induced reinstatement of both heroin and cocaine seeking are mediated centrally.

Finally, it seems unlikely that footshock-induced reinstatement of drug seeking is mediated by analgesic effects of these drugs at the doses used. Observations made during the footshock sessions revealed that both vehicle- and drug-pretreated animals reacted similarly to the footshocks throughout the shock period. These observations are consistent with the finding that clonidine, within a similar dose range to the one used in the present study, does not alter threshold sensitivity to footshock (Soderpalm and Engel 1988).

In conclusion, the present findings may have clinical implications. First, the results presented here may provide a rationale for the use of alpha-2 adrenergic receptor agonists in treatment programs for the prevention of relapse to drug use. Currently, these drugs are being used with some success in the short-term treatment of opioid withdrawal (Lin et al. 1997; Warner et al. 1997). The present findings suggest that they may be effective in the treatment of cocaine users (McDougle et al. 1994) if given for a more prolonged period (see Herman and O'Brien 1997). Second, the present experiments demonstrate a similar efficacy of clonidine and lofexidine in preventing footshock-induced reinstatement of cocaine seeking. This finding is of potential clinical significance in that lofexidine has been reported in humans to be associated with fewer adverse side effects than clonidine, in particular fewer hypotensive effects (Carnwath and Hardman 1998; Kahn et al. 1997; Lin et al. 1997).

\section{ACKNOWLEDGMENTS}

Supported by grants from the National Institute of Drug Abuse, the Medical Research Council of Canada, and Fonds pour la Formation de Chercheurs et l'Aide la Recherche (Quebec). S.E. was supported by graduate fellowships from the Natural Science and Engineering Research Council of Canada and Concordia University. We thank Dr. Yvona Buczek and Angela Wang for their expert technical assistance in carrying out the experiment with sucrose-trained rats.

\section{REFERENCES}

Aghajanian, GK, VanderMaelen, CP (1982): alpha 2-adrenoceptor-mediated hyperpolarization of locus coeruleus neurons: intracellular studies in vivo. Science 215: 13941396

Ahmed SH, Koob GF (1997): Cocaine- but not food-seeking behavior is reinstated by stress after extinction. Psychopharmacology 132:289-296

Aston-Jones G, Shipley MT, Grzanna R (1995): The locus coeruleus, A5 and A7 noradrenergic cell groups. In Paxinos G (ed), The rat nervous system. San Diego, Academic, pp 183-213

Bennett D, Lal H (1982): Discriminative stimuli produced by clonidine: an investigation of the possible relationship to adrenoceptor stimulation and hypotension. J Pharmacol Exp Ther 223:642-648

Bremner JD, Krystal JH, Southwick SM, Charney DS (1996): Noradrenergic mechanisms in stress and anxiety: I. preclinical studies. Synapse 23:28-38

Buccafusco J, Lapp C, Westbrooks K, Ernsberger P (1995): Role of medullary $\mathrm{I}_{1}$-imidazoline and alpha-2-adrenergic receptors in the antihypertensive responses evoked by central administration of clonidine analogs in conscious spontaneously hypertensive rats. J Pharmacol Exp Ther 273:1162-1171

Buczek Y, Wang A, Stewart J, Shaham Y (1999): Stress reinstates nicotine seeking, but not sucrose solution seeking rats. Psychopharmacology 144:183-188

Carnwath T, Hardman J (1998): Randomized double-blind comparison of lofexidine and clonidine in the outpatient treatment of opiate withdrawal. Drug Alcohol Depend 50:251-254

Carter AJ (1997): Hippocampal noradrenaline release in awake, freely moving rats is regulated by alpha-2 adrenoceptors but not by adenosine receptors. J Pharmacol Exp Ther 281:648-654

Codd EE, Press JB, Raffa RB (1995): Alpha 2-adrenoceptors vs. imidazoline receptors: implications for alpha-2mediated analgesia and other non-cardiovascular therapeutic uses. Life Sci 56:63-74

Cole B, Robbins T (1987): Dissociable effects of lesions to the dorsal or ventral noradrenergic bundle on the acquisition, performance, and extinction of aversive conditioning. Behav Neurosci 101:476-488

de Wit H, Stewart J (1981): Reinstatement of cocaine-reinforced responding in the rat. Psychopharmacology 75:134-143

Erb S, Shaham Y, Stewart J (1996): Stress reinstates cocaineseeking behavior after prolonged extinction and a drugfree period. Psychopharmacology 128:408-412

Erb S, Shaham Y, Stewart J (1998): The role of corticotropinreleasing factor and corticosterone in stress- and cocaine-induced relapse to cocaine seeking in rats. J Neurosci 18:5529-5536

Erb S, Stewart J (1999): A role for the bed nucleus of the stria terminalis, but not the amygdala, in the effects of corticotropin-releasing factor on stress-induced reinstatement of cocaine seeking. J Neurosci 19:RC35, 1-6

Ernsberger P, Giuliano R, Willette RN, Reis DJ (1990): Role 
of imidazole receptors in the vasodepressor response to clonidine analogs in the rostral ventrolateral medulla. J Pharmacol Exp Therap 253:408-418

Gobert A, Rivet JM, Audinot V, Newman-Tancredi A, Cistarelli L, Millan MJ (1998): Simultaneous quantification of serotonin, dopamine and noradrenaline levels in single frontal cortex dialysates of freely-moving rats reveals a complex pattern of reciprocal auto- and heteroreceptor-mediated control of release. Neuroscience 84:413-429

Grenhoff J, Svensson TH (1989): Clonidine modulates dopamine cell firing in rat ventral tegmental area. Eur J Pharmacol 165:11-18

Guyenet PG (1997): Is the hypotensive effect of clonidine and related drugs due to imidazoline binding sites? Am J Physiol 273:R1580-1584

Hansen S, Stanfield EJ, Everitt BJ (1980): The role of ventral bundle noradrenergic neurones in sensory components of sexual behaviour and coitus-induced pseudopregnancy. Nature 286:152-154

Herman BH, O’Brien CP (1997): Clinical medications development for opiate addiction: focus on nonopioid and opioid antagonists for the amelioration of opiate withdrawal symptoms and relapse prevention. Sem Neurosci 9:158-172

Jaffe JH (1985): Drug dependence. In Kaplan HI, Sadock BJ (eds), Comprehensive textbook of psychiatry. Baltimore, Williams and Wilkins, pp 987-1033

Jordan S, Jackson H, Nutt D, Handley S (1993): Central alpha-2 adrenoceptors are responsible for a clonidineinduced cue in a rat drug discrimination paradigm. Psychopharmacology 110:209-212

Kahn A, Mumford J, Rogers G, Beckford H (1997): Doubleblind study of lofexidine and clonidine in the detoxification of opiate addicts in hospital. Drug Alcohol Depend 44:57-61

Kalivas PW, Duffy P (1993): Time course of extracellular dopamine and behavioral sensitization to cocaine I. Dopamine axon terminals. J Neurosci 13:266-275

Kreek MJ, Koob GF (1998): Drug dependence: stress and disregulation of brain reward systems. Drug Alcohol Depend 51:23-47

Lal H, Yaden S (1985): Discriminative stimuli produced by clonidine in spontaneously hypertensive rats: generalization to antihypertensive drugs with different mechanisms of action. J Pharmacol Exp Ther 232:33-39

Lategan AJ, Marien MR, Colpaert FC (1990): Effects of locus coeruleus lesions on the release of endogenous dopamine in the rat nucleus accumbens and caudate nucleus as determined by intracerebral microdialysis. Brain Res 523:134-138

Lê AD, Quan B, Juzystch W, Fletcher PJ, Joharchi N, Shaham Y (1998): Reinstatement of alcohol-seeking by priming injections of alcohol and exposure to stress in rats. Psychopharmacology 135:169-174

Li J, Takeda H, Tsuji M, Lui L, Matsumiya T (1998): Antagonism of central CRF systems mediates stress-induced changes in noradrenaline and serotonin turnover in rat brain regions. Meth Find Exp Pharmacol 20:409-417

Lin SK, Strang J, Su LW, Tsai CJ, Hu WH (1997): Doubleblind randomised controlled trial of lofexidine versus clonidine in the treatment of heroin withdrawal. Drug Alcohol Depend 48:127-133

Mantsch JR, Goeders NE (1999): Ketoconazole blocks the stress-induced reinstatement of cocaine-seeking behavior in rats: relationship to the discriminative stimulus effects of cocaine. Psychopharmacology 142:399-407

McDougle C, Black J, Malison R, Zimmermann R, Kosten T, Heninger G, Price L (1994): Noradrenergic dysregulation during discontinuation of cocaine use in addicts. Arch Gen Psychiatry 51:713-719

Murai T, Yoshida Y, Koide S, Takada K, Misaki T, Koshikawa N, Cools AR (1998): Clonidine reduces dopamine and increases GABA in the nucleus accumbens: an in vivo microdialysis study. Pharmacol Biochem Behav 60:695-701

Monti J (1982): Catecholamines and the sleep-wake cycle I. EEG and behavioral arousal. Life Sci 30:1145-1157

Moore R, Bloom F (1979): Central catecholamine neuron systems: anatomy and physiology of the norepinephrine and epinephrine systems. Ann Rev Neurosci 2:113-168

Phelix CF, Paull WK (1990): Demonstration of distinct corticotropin releasing factor-containing neuron populations in the bed nucleus of the stria terminalis. A light and electron microscopic immunocytochemical study in the rat. Histochemistry 94:345-364

Piletz J, Halaris A, Ernsberger P (1994): Psychopharmacology of imidazoline and alpha-2-adrenergic receptors: implications for depression. Crit Rev Neurobiol 9:29-66

Paxinos G, Watson C (1997): The rat brain in stereotaxic coordinates. San Diego, Academic Press

Redmond DEJ, Huang YH (1979): Locus coeruleus and anxiety. Life Sci 25:2149-2162

Roth R, Wolf M, Deutch A (1987): Neurochemistry of midbrain dopamine systems. In Meltzer H (ed), Psychopharmacology: the third generation of progress. New York, Raven, pp 81-94

Sakanaka M, Shibasaki T, Lederis K (1986): Distribution and efferent projections of corticotropin-releasing factor-like immunoreactivity in the rat amygdaloid complex. Brain Res 382:213-238

Self DW, Nestler EJ (1998): Relapse to drug-seeking: neural and molecular mechanisms. Drug Alcohol Depend 51:49-69

Shaham Y, Erb S, Leung S, Buczek Y, Stewart J (1998): CP154,526 , a selective, non peptide antagonist of the corticotropin- releasing factor type 1 receptor attenuates stress- induced relapse to drug seeking in cocaine- and heroin- trained rats. Psychopharmacology 137:184-190

Shaham Y, Funk D, Erb S, Brown T, Walker C-D, Stewart J (1997): Corticotropin-releasing factor, but not corticosterone, is involved in stress-induced relapse to heroinseeking in rats. J Neurosci 17:2605-2614

Shaham Y, Highfield D, Delfs J, Leung S, Stewart J (2000): Clonidine blocks stress-induced reinstatement of heroin seeking in rats: an effect independent of the locus coeruleus noradrenergic neurons. Eur J Neurosci 12:1-11

Shaham Y, Stewart J (1995): Stress reinstates heroin-seeking in drug-free animals: an effect mimicking heroin, not withdrawal. Psychopharmacology 119:334-341 
Shimizu N, Nakane H, Hori T, Hayashi Y (1994): CRF receptor antagonist attenuates stress-induced noradrenaline release in the medial prefrontal cortex of rats. Brain Res 654:145-148

Smagin G, Zhou J, Harris R, Ryan D (1997): CRF receptor antagonist attenuates immobilization stress-induced norepinephrine release in the prefrontal cortex in rats. Brain Res Bull 42:431-434

Sinha R, Catapano D, O’Malley S (1999): Stress-induced craving and stress response in cocaine dependent individuals. Psychopharmacology 142:343-351

Soderpalm B, Engel JA (1988): Biphasic effects of clonidine on conflict behavior: involvement of different alpha adrenoceptors. Pharmacol Biochem Behav 30:471-477

Stanford S (1995): Central noradrenergic neurones and stress. Pharmacol Ther 68:297-342

Stewart J (1984): Reinstatement of heroin and cocaine selfadministration behavior in the rat by intracerebral application of morphine in the ventral tegmental area. Pharmacol Biochem Behav 20:917-923

Stewart J, Vezina P (1988): A comparison of the effects of intra-accumbens injections of amphetamine and mor- phine on reinstatement of heroin intravenous selfadministration behavior. Brain Res 457:287-294

Stretch R, Gerber GJ (1973): Drug-induced reinstatement of amphetamine self-administration behavior in monkeys. Can J Psychol 27:168-177

Terenzi M, Ingram C (1995): A combined immunocytochemical and retrograde tracing study of noradrenergic connections between the caudal medulla and bed nuclei of the stria terminalis. Brain Res 672:289-297

Valentino R, Page M, Curtis A (1991): Activation of noradrenergic locus coeruleus neurons by hemodynamic stress is due to local release of corticotropin-releasing factor. Brain Res 555:25-34

Valentino R, Wehby R (1988): Corticotropin-releasing factor: evidence for a neurotransmitter role in the locus ceruleus during hemodynamic stress. Neuroendocrinol 48:674-677

Veinante P, Stoekel M-E, Freund-Mercier M-J (1997): GABAand peptide-immunoreactivities co-localize in the rat central extended amygdala. NeuroReport 8:2985-2989

Warner EA, Kosten TR, O'Connor PG (1997): Pharmacotherapy for opioid and cocaine abuse. Med Clin North Amer 81:909-925 